\title{
THE ENTREPRENEUR'S INFORMATION NEEDS FOR EFFECTIVE INDUSTRIALIZATION IN AFRICA
}

\author{
Amaka Raymonda Obiamalu \\ Nnamdi Azikiwe University, Awka.
}

\begin{abstract}
:
This paper is based on the entrepreneur's information needs for effective industrialization involvement in Africa. Entrepreneurs in various situations need information inputs for planning, implementing, monitoring, financing or reviewing schemes, projects and programs. The purposes for which information is required differ. There may be an immediate need for information to understand the situation an entrepreneur is facing, to convince and persuade others, and to use the opportunities available; or an entrepreneur may gather information to prevent a problem situation arising. This paper also looks at how libraries and librarians can help the entrepreneurs to locate and access information that will aid them in satisfying their information needs in order to compete favourably with their counterparts in other parts of the world.
\end{abstract}

Keywords: industrialization, entrepreneurs, information needs, Libraries and Librarians.

\section{Introduction:}

Entrepreneurship started a very long time ago with an Italian man who embarked on the trade route to the far East. As a middle man, Marco-polo had to sign a contract with a money lender to sell his goods. In the signed contract, the merchant adventurer took a loan at $22.5 \%$ interest. When the merchant adventurer successfully sold his goods, the profit that was realized was shared between him and the money lender who got the lion share. This made the merchant adventurer begin to save money by getting involved in more trade. This merchant adventurer eventually became an entrepreneur managing small and large production projects. The entrepreneur takes the risk of the business, both small and big. In the past decades, people did not take any risk because all they needed to run their business was provided by the government of that country; all the entrepreneur needed do was to manage the business.

In the $17^{\text {th }}$ century, the entrepreneur was seen as a person in agreement with the government to perform or supply stipulated products or service, John Law was one of the entrepreneurs in the $17^{\text {th }}$ century and was the founder of the Royal Bank of France and Mississippi company that had exclusive right to trade between France and the new world but monopoly led to the collapse of the company. Richard Cantillion, a well-known English economist, studied and understood Law's mistake, he observed that an entrepreneur is a risk bearer while the merchants, farmers, craftsmen, and other sole proprietors buy at a certain price and sell at uncertain price which makes them to operate at a risk. This observation led to the differentiation between capital provider and the person that needs capital and the major reason for this differentiation is due to the industrialization that is taking place globally.

\section{Industrialization:}

Industrialization is the structural change that undeveloped countries experience in their development process from an agricultural economy to an industrial economy, with the profound changes in the society (Castellacci \& Natera, 2011). Industrialization is a term that is used to describe a process of economic and social discovery for efficient and effective means of creation and innovations which add value to the economy. Industrialization is a process and not an event. A process is an emergent property of a system resulting from a collection of 
activities that share time scale than that of component events (Fagerberg, Shrolec and Verspagen 2010).

\section{The Entrepreneur:}

A complementary picture of an entrepreneur follows that of the eighteenth-century economist, Richard Cantillon, who emphasized the literal interpretation of the term as someone who "undertakes" the risks of a business or enterprise. An entrepreneur is referred to as a person who starts and manages his or her own businesses (Stevenson, \& Wei-Skillern, 2006). Entrepreneurs are seen as risk-takers and innovators who reject the relative security of employment in large organizations to create wealth and accumulate capital by themselves. Entrepreneurs can be seen as "dreamers who do". The entrepreneur is a person with a vision, and the commitment to make that vision a reality (Murari, 2009). An entrepreneur can also be defined as a person who habitually initiates, creates and innovates and builds something of recognized value at any given opportunity. Some scholars also are of the opinion that an entrepreneur is a person that is willing to take the risks of a new venture if there is a profit and Peter Drucker saw an entrepreneur as a person who goes in search of change, responds to the change and takes advantage of the change to create values that will improve the situation on the ground. This change that has been exploited will change the market demands that are not satisfied at that period. So, for the entrepreneurs to be fully involved in their new adventure, they need information that will enhance their activities, creativity and innovations (Osman and Murat, 2011).

\section{Information Needs:}

'Information needs' may often be complicated by the confusion over the definition of the concept 'information'. The concept "information" can be defined in several ways depending on the perspective from which it is being looked at. Murari, 2007 opined that information is an instrumental value by which people achieve some values that will contribute to basic elements of a system. Murari stated that information is associated with human situations via a communication medium. In the business environment, information can be defined as a structured, meaningful statement on reality that will serve a purpose. In this study of the information needs of the entrepreneurs, it is vital to understand the nature of business information and the purpose of business information in an enterprise as a basis for making decisions that will lead to effective involvement in industrialization (Nagarkar, 2011).

The Information needs of an entrepreneur arise when the amount of know-how possessed by the sole proprietor is inadequate to cope with problems emanating from various business situations. In a small business entity such as micro business, seeking information is crucial since the function is handled totally by one person (Murari, 2009). Hence, entrepreneurs must search for information on their own since information plays a vital role in ensuring survival and success in business and is considered one of the essential ingredients for a successful entrepreneurship. Many entrepreneurs think that there is no need for information or they might just pick information from any source to start their business; the important thing here is that people need information to be successful entrepreneurs. The bone of contention here is the type of information the entrepreneurs need for their business to be sustained and successful. 


\section{Types of information that is needed by an entrepreneur, according to Ikoja-Odongo (2001): \\ - Location of the business premises information \\ - Capital and loan information \\ - Production information \\ - Policy information \\ - Legal information \\ - Technical information \\ - Consumer information \\ - Training information \\ - Human resources information}

Entrepreneurs need to be reminded at all times about the basic information needs regarding their enterprise so that they can be up to date in their business for effective industrialization.

\section{Location of Business Premises Information:}

The entrepreneur's, first step in setting up his business is to consider the location where the company will be located. This is informed by the type of business that is intended to be carried out. When considering the location, there are certain things the entrepreneur will bear in mind such as access to raw materials that will be used in the course of production, access road and power supply. All these have to be taken care of before sourcing for funds to finance the business.

\section{Capital and Loan Information:}

An entrepreneur needs information on how to raise money for his business, whether small or large. Most of the time, this issue of capital is overlooked by the entrepreneurs and it causes a lot of setbacks for the business. This aspect is usually referred to as the back-office aspect of the enterprise; this financial information plays a vital role in decision-making. Decisions must be based on good information available. It is only when there is good information on financial situations that the entrepreneur will be able to know the exact amount of capital that will be invested in the business and that will help him also in sourcing the money to start-up the venture. It is not strange that money is required for the purchase of the machineries and equipment, payment of rent, hiring the resource persons, and paying for other exigencies. So the entrepreneur needs to plan all these expenses and make provision for an extra $20 \%$ of his budget as take-off capital to ensure sustainability. There are various means through which an entrepreneur can source money for his business. These include personal savings, grants from government, grants from Non-governmental organizations, international funding agencies, borrowing, either from friends or banks.

\section{Technical Information:}

For a potential entrepreneur to be successful, there is a need to carefully source for and adopt intelligent technical approach. In managing a business, planning can never stop as it is very necessary for an entrepreneur, at the early stage of the business, to put in place a preliminary business plan. There are various types of technical information that will be vital as part of business operations such as the aesthetic design of the business environment, how to design the product, packaging of the products, the type of services he may wish to be engaged in, tools and equipment, and raw materials for the production, and it can also include means of production either more or less mechanized, more or less manual. 


\section{Information and Communication Technology (ICT):}

Information and communication technology is a very vital means of information for the entrepreneurs' development as it is certain that ICT has made the whole world a global village. With the help of ICT, the entrepreneur can go online to source and access information on any product or service. There are so many business databases online that an entrepreneur can lay hands on for any type of information that is required. Entrepreneurs use new technologies to produce new products and services, hence they should take cognisance of the fact that cell phones and the internet increase the rate of exchange of information which may have an effect on their business operations (Nagarkar, 2010). Entrepreneurs should always look out for software that will enhance their business operations even though they may not be aware of all the technological developments in their operational areas. The internet has enabled computer users to be linked through network and this has revolutionized trading by bringing together people from all over the world. Hence, many of these features can be used to shape a new business. As an entrepreneur, the individual must be in communication, with suppliers, middle men, consumers, etc. With the internet facilities being available, the entrepreneur can cover enough business areas within a short period. With internet facilities the entrepreneur goes into research to know what is the latest in their area of innovation. The web is a collection of texts and multimedia resources that help to create huge electronic library. Website pages of print and visual information that are connected electronically give the entrepreneurs the opportunity to advertise their products and services globally, they project the entrepreneurs and their innovations.

\section{Legal Information:}

Business is a means of economic development of any nation. This business operation could be a small business, medium or large-scale enterprise which could be national or international in scope. Irrespective of the level at which the entrepreneurs operate their business, they must know the legal aspects to their operations. For instance, if one wants to establish a private company here in Nigeria, the minimum number of people is two and the maximum is fifty and it must be registered under Corporate Affairs Commission (CAC). The entrepreneur needs to know how the copyright law as well as trade mark and patent law works. According to Okeke (2011), the copyright law deals with the exclusive right given to inventors for a definite period of years as a means to protect their interest and to encourage them to invent more things valuable and useful to the society. As the Business and Industry Advisory Committee to the Organization for Economic Cooperation and Development (OECD) stated in 2003, the government should put in place Policies that will foster entrepreneurship as they are essential to job creation and economic growth. Government officials can provide incentives that encourage entrepreneurs to risk attempting new ventures. Among these are laws to enforce property rights and to encourage a competitive market system. The culture of a community also may influence how much entrepreneurs strive within that community. Different levels of entrepreneurship may stem from cultural differences that make entrepreneurship more or less rewarding personally. A community that accords the highest status to those at the top government-paid jobs or those with professional expertise may discourage entrepreneurship. A culture or policy that accords high status to the self-made individuals is more likely to encourage entrepreneurship (Okeke, 2011).

\section{Marketing Information:}

An entrepreneur needs to come up with innovative and creative ideas that will serve as the starting point for the new venture. Sometimes, an entrepreneur sees a market need and initiates an idea for a product or service to take care of it. At times, an entrepreneur may get an idea for 
a product or service and source a market for it. As an entrepreneur, there is the need to be constantly engaged. Research, timing, and a little luck transform commonplace ideas into successful businesses. People get ideas from reading various articles and books; entrepreneurs should interact with people and make enquiries on the existing products and services and look for what is lacking in the existing products and services and initiate a means to improve on them. An entrepreneur looks out for the things that people will like but which are not yet available and provides it for the masses and can also go into packaging and repackaging of the products that are in existence and make them look more attractive. It will also help in the improvement of the quality of already existing products. An entrepreneur can also produce goods that are already in existence for an already existing market. In this case, he must find a way to convince the consumers of the need to patronise him and also face the challenges of competing with already existing marketers or entrepreneurs. This may cause him to reduce the selling price while producing a high-quality product and ensuring that the product is well advertised through various means; all these will make his start-up cost high and the profit will be uncertain. This is one of the reasons why an entrepreneur must ensure that there is sufficient start-up capital. With all this information, entrepreneurs should be successful and sustained in their business endeavour, seeking for this information will be better accessed through the libraries. There are different types of libraries: the National, academic, public, and school, special and private libraries. The type of library that is established depends on the needs of clienteles to be served.

\section{The Library:}

The library is a social institution that is meant to collect, organize, preserve and disseminate information to its patrons. The library is not just a place to go and read books solely to pass examinations, but it is a place where other people's ideas, innovations and creativities are found. The library, having collected and preserved the materials, is meant to serve people to meet their various information needs, and an entrepreneur is one of the potential clients to the library be it public, academic or special libraries (Okeke, 2011). The discussion on the role of the library in information provision to the entrepreneurs will be focused on the public and academic libraries.

\section{Public Libraries:}

A public library is an organisation or institution offering information services to the general public and is operated by information professionals who are referred to as librarians (Gichohi, 2016). Libraries are traditionally known for performing four major functions. They are informative, educational, recreational and cultural (Santos, 2009). Libraries contribute immensely to the nation's literacy development and lifelong learning. Public libraries serve as the main information resource centres for rural communities and other disadvantaged groups. In 1996, UNESCO's manifesto on public libraries highlighted the expanded mission of public libraries in providing information services adapted to the local business communities (Santos 2009). According to Santos, the origin of public libraries' provision of information services to business people is based on the Community Information Service (CIS) with examples from both Great Britain and the United States in the nineteenth century.

\section{Academic Libraries:}

Academic libraries are libraries that are attached to the university to support the teaching, learning and members of the institution that they are serving. (Abubakar, 2011) is of the opinion that a university library is an integral part of the parent institution that is established to aid the academic and innovative activities in the institution, adds that there will be no university that 
will be approved without a library. (Reitz, 2004) defines academic library as a library system established, administered, and funded by a university to meet the information, research, and innovation needs of its students, faculties and staff members of the university community. From the definition given by Reitz, it can be said that a university library is a library that is situated in the university to provide the information needs of the institution. Some large universities have separate libraries for the undergraduate and post-graduate students. All these are meant to support the teaching, learning, creativity and research carried out in the universities. Momodu (2011) opines that the university libraries are libraries known for acquiring information resources and making them available to their users. Momodu also defines a university library as the heart of the university and which uses the human and material resources at its disposal to support teaching, learning and research objectives of the institution. In the words of Nwezeh and Shabi (2011), the academic libraries have information dissemination as their predominant function. Specifically, they see the university library as engaging in the collection, processing, preservation and dissemination of recorded information in the various formats most convenient to its target users. Considering this function of the library therefore, behind the mission and vision of education and innovation is the library.

For the libraries to meet up with the information needs of the entrepreneurs, libraries must play a direct role in supporting the next generation of entrepreneurs to get their start. The primary way to do this is through the development and collection of the following:

\section{Libraries Roles in Information Provision for the Entrepreneurs:}

- Library space to support innovation

- Library resources for the entrepreneurs

- Selective dissemination of information

- Library instructions

- Literature search

\section{Library Space to Support Innovations:}

Maker space is also known and referred to as fablabs and it is a space in the library that is created for collaboration, irrespective of the field of study, where people meet to do creative work in projects, invent new ones and share ideas. Many libraries offer community resources such as 3D printers, software, electronics, craft and hardware.

As universities are trying to produce students who will become entrepreneurs after they have left the university, many academic libraries have begun to provide access to maker resources and services. A maker space will be useful for innovation and collaboration when the students who will become the future entrepreneurs are educated and skilled on how to use it. Users need to learn how to use 3D model and design, in order to use 3D printer to design their own creations. Skills on computer programming and hardware development will also be vital to prototype on common maker-space. As an entrepreneur if you need a prototype of your product, the library will provide it for you through the use of 3D printer. A growing number of libraries have maker-spaces and other workspaces to help you realize your vision. 


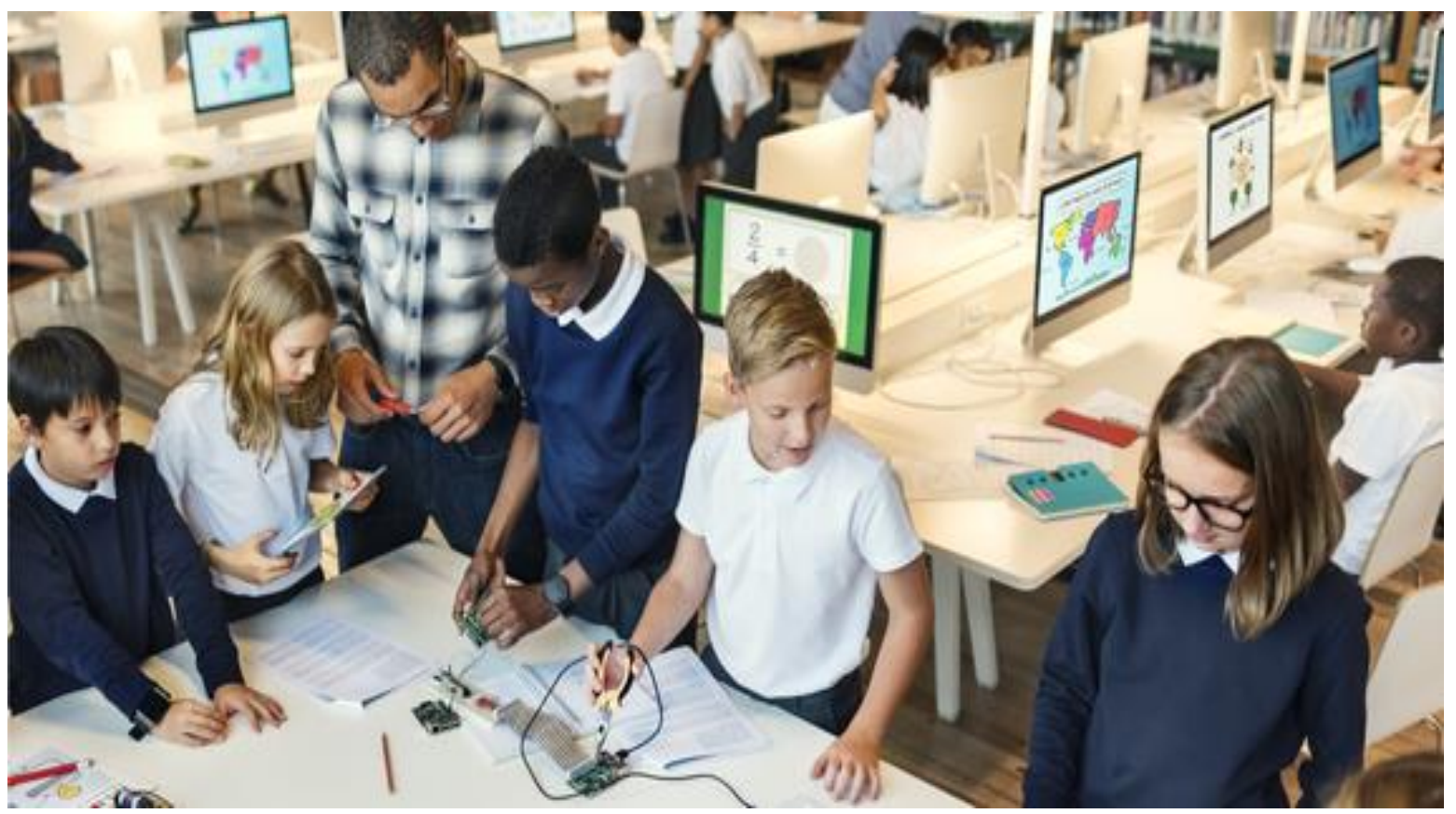

This diagram is a picture of a maker-space in the library

\section{Library Resources for the Entrepreneurs:}

The library resources or library collections are the information materials that have been acquired, processed and stored for information dissemination. For the library to meet the information needs of the entrepreneurs, the librarian has to know the area of business venture that the entrepreneur is interested in and collect materials that will help him to improve on the business venture that he has undertaken. These collections will be a specialised book, databases, and reference materials written by experienced entrepreneurs who have written documentations on how and what they did to become successful entrepreneurs. As an entrepreneur, research should be one of the basic things to be done on daily basis, and due to the busy schedule that the entrepreneur has the librarian becomes the best person to help in the literature search and then package it in such a way that, at a glance, the entrepreneur will grab the information that is needed for decision-making or for planning or implementation. The libraries also provide access to expensive materials that cost thousands of dollars to purchase and prohibitive research and reference materials for the entrepreneurs thus making it possible for the materials to be available to everyone without any cost.

\section{Library Instructions for the Entrepreneurs:}

Library instructions are the library programs and services that are given to the entrepreneurs to keep them informed on what is current in their area of business venture, this includes series of free workshops and seminars covering topics such as the copyright law, information on trademarks, government policies on the business, and intellectual property rights. They also need information on how to register their business venture in the corporate affairs of the nation, with library instruction by the library; entrepreneurs can also know the situation of inflation in the country. So, it is advisable for the entrepreneurs to make proper use of the library to boost their business. Talking about Intellectual Property Resources you have to ensure that before an entrepreneur commits himself to creating the best product ever, he should be sure that someone hasn't already created it. For you to know, libraries can provide the resources and know-how to check for patent and trademark information so you don't waste valuable time and resources or get yourself into a sticky legal situation. If you are an entrepreneur, an established business 
owner, or just thinking about starting a business, head for the library. You will be pleasantly surprised at the role the librarian, with the help of the library resources, can play in helping you start and grow your business. Those roles mentioned are just part of what the library can offer you, so you as an entrepreneur are encouraged to make the library your second office and see how your business will grow.

\section{Conclusion:}

The library is the institution where information materials are acquired and stored for the general public to access. It has also been said that information is knowledge, and when one is not informed, the person will be deformed. So, to remain relevant in the society you live in as an entrepreneur, you need information, and that information that you need to be equipped with is stored in the library. It will, therefore, be vital for everybody, both entrepreneurs and intending ones, to always make use of the library. There are innovations in the library that can help entrepreneurs to move to the next success level if only they can make use of the library. They should not forget that the librarian is in the library waiting to meet their information needs. Whatever they need to know about their entrepreneurial journey, the librarians at the local library can help. They either know the answer to your question or they know how to find the answer. Librarians are the superpower of libraries. Go to them for entrepreneurial helpand you will not be disappointed. Librarians do not say, "I don't know". "Sorry", they say, "I don't know." Let's find out."

\section{Recommendation:}

From the discussion, it will be of great importance if the Nigerian government will look for a means to encourage entrepreneurs in this country. We have the skills to initiate and invent new products that will have value and be meaningful in our society but the major problem is that those who will want to be self-employed do not have start-up capital and, as such, will not be able to meet the demand of starting their own business.

People do not make use of the library properly to seek for information, rather, they use the informal means of seeking for and obtaining information, so it is recommended that the librarians should always create awareness for the entrepreneurs that are always busy and may not have time to come and look for one information material or the other.

\section{References}

Castellacci, F., \& Natera, J. M. (2011). A new panel dataset for cross-country analyses of national systems, growth and development (CANA). Innovation and Development, $1(2)$.

Fagerberg, J., and Srholec, M. (2008), National innovation systems, capabilities and economic development, Research Policy, 37: 1417-1435.

Fagerberg, J., Shrolec, M., \& Verspagen, B. (2010). "Innovation and Development". In B. Hall \& N. Rosenberg (eds.). Handbook of the Economics of Innovation, North Holland: Elsevier. pp. 833-872.

Fagerberg, J., Srholec, M., \& Knell, M. (2007). The Competitiveness of Nations: Why Some Countries Prosper While Others Fall Behind, World Development, 35(10), 1595-1620.

Gichohi, P.M. (2016). Role of public libraries in the development of small-scale business enterprises in Meru cCounty Kenya. Doctoral dissertation in university of South Africa. 
Ikoja-Odongo, R. (2001). A study of information needs and uses of information sector in Uganda. Preliminary findings. Library and information Science Research Electronic Journal.

Kansas City, Missouri. Accessible at http://www.kauffman.org//media/kauffman_org/research-reports-andcovers/2013/08/eshipedcomesofage_report.pdf).

Kauffman Foundation (2013). Entrepreneurship Education Comes of Age on Campus: The Challenges and Rewards of Bringing Entrepreneurship to Higher Education (p. 1).

Murari, D. (2007). Information needs analysis and information seeking behaviour of Entrepreneurs with special reference to women. Thesis available online at: http://shodhganga.inflibnet.ac.in/handle/10603/6404

Murari, D. (2007). Information needs analysis and information seeking behaviour of Entrepreneurs with special reference to women. http://shodhganga.inflibnet.ac.in/handle/10603/6404

Murari, D. (2009). Information Seeking by Entrepreneurs (co-authored with Harsha Parekh) at the Eighth International Biennial Conference On Contemporary Issues in Entrepreneurship Research at the Entrepreneurship Development Institute, Ahmedabad.

Nagarkar, S. \& Parekh, H. (2010). Fungal Species Information. Berlin: Lap Lambert Academic Publishing.

Nagarkar, S. (2011). Web based information services to Bioinformaticians: challenges for librarians. IFLA WLIC 2011. http://conference.ifla.org/sites/default/files/files/papers/ifla77/111-nagarkar-en.pdf

Okeke, E Ifeka (2011). Library as a research institute. Published by ifevic, Oba Anambra State

Osman, E. \& Murat, P. (2011). Entrepreneurship, National Culture and Turkey. International Journal of Business and Social Science 2 (16).

Sathe, N.A., Jerome, R., \& Giuse, N.B. (2007). Librarian-perceived barriers to the implementation of the informationist/information specialist in context role. Journal of the Medical Library Association JMLA, 95(3), 270-274.

Schauder, Don (1987) Entrepreneurship and the academic library: Insights from organization theory. Iatul Quarterly 2( I) 36-50 The 12th Biennial Conference, Helsinki Australia

Stevenson, A.J.H \& Wei-Skillern, J. (2006). Social and Commercial Entrepreneurship: Same, Different, or Both? Entrepreneurship Theory and Practice: 1-22.

Tara Radniecki \& Chrissy Klenke (2017). Academic Library Makerspaces: Supporting New Literacies \& Skills Nevada, Reno-University Libraries, DeLaMare Science \& Engineering Library. 